\title{
Audience-Based Brand Equity: A Research on "Women's Tennis Association Championships Istanbul 2013"
}

\author{
Ömer Kürsad Tüfekci ${ }^{1}$ \\ ${ }^{1}$ School of Tourism and Hotel Management \& Sport Science Research and Application Centre Isparta/Turkiye, \\ Süleyman Demirel Universtiy, Turkey \\ Correspondence: Ömer Kürsad Tüfekci, School of Tourism and Hotel Management \& Sport Science Research \\ and Application Centre Isparta/Turkiye, Süleyman Demirel Universtiy, Turkey. E-mail: omertufekci@ @du.edu.tr
}

Received: July 2, 2014

doi:10.5539/ibr.v7n9p141
Accepted: July 31, 2014

Online Published: August 25, 2014

URL: http://dx.doi.org/10.5539/ibr.v7n9p141

\begin{abstract}
Sports organizations, apart from being a product of the popular culture, through their increasing economic contributions and social functions, they have become a global industry. The sectoral structure of sports reveals the strategies for consistently purchasing by consumers. In this context, the strategy in the research's literature is called as consumer-based brand equity and it is adapted with the name "Audience-based Brand Equity" for the sports sector. So in this research it is aimed to analyze "Audience-based Brand Equity" by measuring brand equity under the "WTA Championships 2013" tennis tournament and adapt it to sports marketing literature. Therefore, the perception of the sports consumer had been tried to be measured by using the "Audience-based Brand Equity", by a research performed on "WTA Championships 2013" tennis tournament. By using a questionnaire form, a research data-set had been obtained. In order to test obtained-data, confirmatory factor analysis, multiple-group confirmatory factor analysis and structual equation modeling were used. The findings obtained by research support, the elements of audience-based brand equity for the "WTA Championships Istanbul 2013". Thus, a result has been achieved that the quaternary structure existing in research model and forming the audience-based brand equity is valid and reliable.
\end{abstract}

Keywords: sports marketing, audience-based brand equity, sport consumer, tennis, Turkey

\section{Introduction}

Brand Equity brings several advantages such as more profitability, brand extension opportunities, more powerful communication activity and purchasing intent to the organizations (Keller, 1993; Cobb-Walgren et al., 1995; Buil et al., 2008). Therefore, since the formation of consumer-based brand equity in consumer's minds (Keller, 1993), it is required to approach from a strategic point to the brand management (Wood, 2000). With the changing conditions of competition, attracting the audience in sports market into the organization areas is getting extremely difficult. The reason of this is the changing of consumer expectations and rapid increase in the sports industry as in each industry (Rein et al., 2007:30). Changing consumer expectations are met by the organization and differentiation from competitors with different aspects, are easily recognized by consumers and the organization will be positioned in the minds of consumers. This result is a combination of brand awareness occurred in the consumer's mind, brand loyalty, perceived quality and brand associations and all positive and negative thoughts formed in consumer's mind.

A clear focus of the aims of the research to measure brand equity on "WTA Championships Istanbul 2013" tennis tournament and to analyze "Audience-based brand equity" and adapt it to the sports marketing literature. Besides, this study contributes to scale validation as well as understanding of the benefits of brand equity on sports industry. Also considering the emotional behaviors displayed by audiences in sports events, it will provide important clues regarding the sports marketing. Therefore the results of this study have of importance because of its contribution to the sports marketing literature.

In this study, a research was conducted on "Women's Tennis Association (WTA) Championships Istanbul 2013" in order to analyze "Audience-based Brand Equity" model and to adapt sport marketing literature. The findings obtained in this study are attempted to be transferred in a certain sequence. First the conceptual explanations and literature related to brand equity will be mentioned. Then the "Audience-based Brand Equity" model and the variables forming this model will be explained. The purpose and importance of this research, its scope and 
limitations, its model, sample selection and size of sample, data collection methods and tools and data analysis processes will be explained in this study. The findings obtained will be evaluated and reviewed in the last section and the suggestions will be made for the potential works in future in this area.

\section{Brand Equity and Related Literature}

Nowadays, the concept of a brand is not only an issue focused by the business; it is also a phenomenon intensified by individuals, institutions, organizations, destinations, cities, regions or even countries. In addition to this, with brand concept has been emphasized different directions with different perspectives. Creating a brand and the brand equity depends on importance and strategic advantage of achieving a competitive advantage that attract the attention of academics as well as practitioners (Erdem et al., 1999; Kim and Kim, 2005). The brand equity in this context has become a concept which is oftenly focused and researched. When literature was analyzed, it has been approached to brand equity from several different viewpoints (Farquhar, 1989; Aaker, 1991; Keller, 1993). It is discussed in terms of Brand Equity; additional value raised by the brand name (Farquhar, 1989); favorable impressions, behavioural requests and behavioural preferences (Rangaswamy et al., 1993); brand awareness, brand loyalty, brand image and perceived brand quality (Aaker, 1991); differentiator effect of brand-knowledge on consumer response to the brand marketing (Keller, 1993); increasing utility (Simon and Sullivan, 1993); total utility (Swait et al., 1993); difference between the general brand preference depending on measured qualities and the multi-featured choice (Park and Srinivasan, 1994); total quality and choice-intent (Agarwal and Rao, 1996).

Many different definitions regarding the brand equity in literature results the concept variety of brand equity (Winters, 1991: 70) and the absence of a definition generally accepted (Kayaman and Arasli, 2007: 94). The researchers conducted on brand equity prove to cover many areas of psychology such as cognitive, social, personality and neuroscience (Hilgenkamp and Shanteau, 2010: 562). Due to approaching to the concept of brand equity with a perspective of consumer-based, consumer-based studies existing in the marketing literature are emphasized.

A powerful brand equity depends on brand awareness, brand loyalty, brand image and perceived brand quality, all these can be formed through a clear identification, a collective brand, consistent and coherent communication, strong customer relationships and creation of symbols (Aaker, 1992). According to Kapferer (2004), a brand's strength is shown by market, product price, distribution or communication with a total brand experience indicates the actual product or services within all sources.

Brand equity in general is expressed in terms of marketing efforts depending on the brand, for example, when a product or service is marketed with a brand name, its revenue will not be the same as the one without a brand name (Keller, 1993: 1o). Brand equity is defined by Aaker (1991: 15) "a set of assets and liabilities linked to a brand name or a brand symbol which add to or subtract from the value provided by a product or service". In addition to "the value added by a product or a brand" definition (Farquhar, 1990: RC7), this added value may be evaluated from the viewpoint of consumer or business and can be stated as it is analyzed (Erdem and Swait, 1998: 132).

Upshaw (1995: 14) also defines the brand equity "the total accumulated value or worth a brand, the tangible and intangible assets that be brand contributes to its corporate parent, both financially and in terms of its selling leverage". Brand equity is created by using applications such as advertising expenditures, sales force, public relations, slogans, symbols, packagings, warranties and activity marketing (Tong and Hawley, 2009: 566). Brand equity is oftenly described in the literature with its intangible brand features (Aziz and Yasin, 2010: 181). In particular, the interest in brand equity has increased as a result of reporting of financial value of intangible assets, changing in international accounting standards and impact of marketing activities on brand performance (Wood, 2000: 662; Eagle et al., 2003: 1332).

Considering all the definitions made for the brand equity, it can be said that it is linked to consumer perception, general value, brand name, competition and the features that affects financial performance (Lassar et al., 1995: 12).

Brand equity that can also be expressed as the power of brand structures with the creation of assessment criteria in the consumer's mind and is directly related to buying behaviour as a result of customer satisfaction (Na et al., 1999). While brand equity, offers advantages such as increasing confidence and continuity of customer satisfaction without causing any confusion for the consumer; it also gives a direction for the business such as increasing marketing effectiveness, creation of brand loyalty, increasing profitability, revealing the distinctive capabilities and differentiation from competitors (Lin and Kao, 2004: 37). 
Despite brand equity's many conceptualizations and overall lack of consensus on an exact definition, it is observed that some researches came to an agreement around the meaning in terms of adding value to a brand (Ross, 2006). So some successful brands by establishing strong emotional and personal relationships with its customers, create trust for brand loyalty and purchase decisions (Aaker, 1996). This is closely related to professional sports in terms of developing a strong emotional bond for consumer's favorite sport or team (Hong et al., 2005; Mullin et al., 2007).

There are three different approaches shaping brand equity called as customer-based approach, financial-based approach and business-based approach (Kim et al., 2003; Kim and Kim, 2005; Keller and Lehmann, 2006: 744-745). In the figure below are given these three approaches and main elements of them.

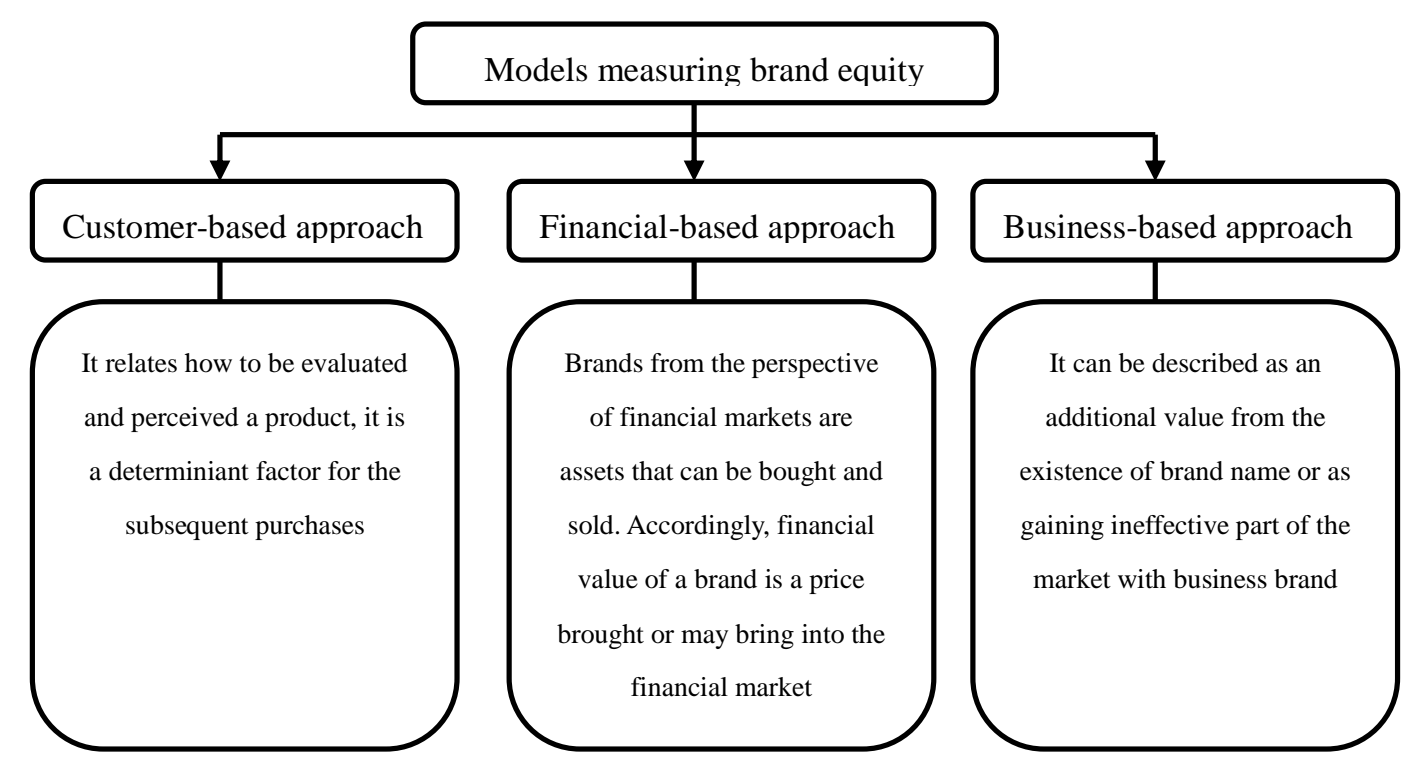

Figure 1. Models measuring brand equity

Source: It has been transformed into figure making use of Simon and Sullivan (1993: 29), Dyson et al. (1996), Thode and Maskulka (1998: 382), Kim et al. (2003: 336), Keller and Lehmann (2006: 744-745), Broyles et al. (2010: 168).

In similar studies in the literature that have been obtained different results. Filo et al. (2008) by his studies on sports and fitness centers has assigned that the features related and non-related product have an effect on brand confidence. Bauer et al. (2008) also by his study on German football teams, has assigned that the features related and non-related product have a positive effect on benefits and these benefits also have a positive effect on attitudinal loyalty. Kabadayı and Aygün (2007), Lau and Lee (1999) have found that brand confidence affects the brand loyalty. There are so many researches in the literature that indicate the brand confidence has an effect on attitudinal loyalty and brand loyalty (Garbarino and Johnson 1999; Chaudhuri and Holbrook, 2001; Javadein et al., 2008; Filo et al., 2008; Kim, Morris and Swait, 2008; Y1ldız et al., 2012).

Customer-based approach will be emphasized in terms of forming the scope and focal point of this study. In addition, study will be referred as "Customer-based Brand Equity" and "Audience-based Brand Equity" by associating audience who is the customer of the sports industry.

\section{Audience-Based Brand Equity}

Customer-based brand equity is further concerned with the decision-making process of the consumer and involves identification of the source of brand value in order to improve effectiveness of marketing activities (Aaker, 1991; Park and Srinivasan, 1994; Agarwal and Rao, 1996). Audience-based brand equity undertaken within the customer-based brand equity relates how to be evaluated and perceived a sport product that is a decisive factor for the subsequent choices (Broyles et al., 2010: 168).

In recent years the studies that are related to brand equity in the literature which are covered by the sports sector marketing has been drawing increased attention of the researchers (Bauer et al., 2008; Gladden and Funk, 2002; Ross, 2006; Ross et al., 2008; Biscaia, 2013). Nowadays, many studies are focused on a unique-dimension of 
brand value and being formed without consideration of distinctive nature of professional sports (Ross, 2006). One of the first studies uses a multi-dimensional perspective for brand equity in sports industry that was developed by Gladden et al. (1998).

Audience-based brand equity can be defined as the differential effects on consumer's response for marketing a brand (Keller, 1993: 2). However, it may be referred as the added value of brand to customer (Mackay et al., 1997: 1153). This approach focuses on the value perceived by the audience as a result of marketing activities (Pappu et al., 2005: 144).

This study focuses on approach referred as the basis of audience-based brand equity however expressed as consumer-based brand equity in literature. Brand equity has become field of interest of researches because of determining brand strategies and effectiveness, making strategic assessments and its role on financial benefits (At1lgan, 2005: 39).

Brand equity in marketing researches are realized in two types of measurements such as consumer perception (brand awareness, brand associations, perceived quality) and consumer behaviour (brand loyalty) (Cobb-Walgren et al., 1995: 26). In addition there are also studies that interested in perceptual dimension and measure the brand equity with performance, social image, value, reliability and commitment dimensions (Lassar et al., 1995).

A brand equity arises from the consumer perception of a brand affected by various factors (Chattopadhyay et al., 2009: 109-110). Therefore, it is difficult to understand brand equity without carefully reviewing the influences on overall perception of sport consumer. In this context, audience-based brand equity and brand awareness, brand knowledge consisting of brand image, brand's marketing and it's impact on sport consumers' response can be measured (Keller, 1993). Based on brand equity dimensions conceptually described, a multi-dimensional consumer-based brand equity is developed (Yoo and Donthu, 2001; Aaker, 1991; Keller, 1993). It can be considered that adapting audience-based brand equity, using of this scale may contribute to the literature. Therefore, it is attempted to test the brand equity in this study.

In the research, audience-based brand equity is handled in four dimensions. These are; brand awareness, brand associations, perceived quality, and brand loyalty dimensions.

\subsection{Brand Awareness}

Brand awareness, is the power of existence of a brand in consumer's mind. In this context the term recognition is measured according to different remembering ways varying for consumers from recognizing brand to remembering it, from coming to mind firstly to becoming dominant (Aaker, 2009: 24). Aaker (1990) stated brand awareness as the place brand takes in consumer's mind as a result of being compared with rival brands. Aaker (1991) found that brand level consumer created in his mind is determined by going through four stages. These are recognition of brand, remembering of brand, settling the peak mentally, and forming a dominant brand name. Keller (1993), however, stated brand awareness as customer's finding the brand he prefers in his mind and recalling it.

\subsection{Brand Associations}

Brand association being an important dimension of consumer-based brand value component (Aaker, 1991; Keller, 1993), is a quite important term for both consumers and marketers. While brand association for marketers is important for features such as difference of brand, its situation, its enlargement, consumers' senses and attitudes towards brand; brand association for consumers is important for features related to brand immediately connoting in mind, helping their purchasing decision, being found information in mind and recalling (Low and Lamb, 2000: 352). Aaker (1991) stated brand association as everything that consumer creates in his mind related to brand. Hsieh (2004) indicated that brand association provides a basis for being understood the value of consumer-based brand value. Ross (2006) stated that brand association positively contributes to arising consumer loyalty, recognition and image of brand. Brand association which is also a key element of brand image contributes to differentiation and positioning of a brand, creating positive attitudes and thoughts towards brand (Simms and Trott, 2006: 229).

\subsection{Perceived Quality}

Aaker (1991) stated perceived quality as consumer's way of perceiving total quality that forms performance of brand and points that are superior to other brands when he compared product or service with rival managements. Keller (1993) stated that perceived quality contributes to the value of product created in consumer's mind becoming permanent, creating pressure in his subconscious and making for that product. Kotler (2000) stated perceived quality as creating close ties among profitability of management, consumer satisfaction, service quality and product. Jacobson and Aaker (1987) indicated that perceived quality has a positive impact on 
profitability of managements.

\subsection{Brand Loyalty}

Jacoby and Kyner (1973) stated brand loyalty as consumer's situation of demanding brand psychologically through individual decision making towards the brand which has one or more alternatives. Aaker (1992) indicated the term of consumer loyalty as one of the critical dimensions of a powerful brand. Dick and Basu (1994) stated brand loyalty as consumer's following management for a long time to repurchase the product; Solomon (1994) stated brand loyalty as consumer's making purchasing decision in the event that brand satisfies him; Fournier and Yao (1997) stated brand loyalty as the center of marketing strategies and tactics of managements. Dick and Basu (1994), Rundle-Thiele and Mackay (2001) and Toylar et al. (2004) revealed that behavioral dimension affects brand loyalty positively or negatively, as well. The term commitment which is also called as repurchasing, preference or loyalty reduces the time consumers spend for doing a wide research among product alternatives. Purchasing decision of consumers with high commitment can become simple and in time can become a pattern (Rundle-Thiele and Mackay, 2001: 529).

\section{Research}

Research was carried out by a hierarchy intended for empirically evaluating of the theoretical framework. So initially, the purpose and importance of the research have been revealed that was already created within the theoretical framework. The purpose of the study was to create scope of research and its certain limitations. Thus, a data-analyze was made according to data-collection methods selecting the sample as part of the proposed research model. In this section, the steps in the research process will be explained.

\subsection{Purpose and Importance of Research}

In conceptualization of brand equity in sports industry, must form the focal point of consumer experience due to being unique events and causing emotional responses in a wide range (Madrigal, 2003). Accordingly, in this study using the "Audience-based brand equity", the perception of sport consumer has been attempted to be measured by a research conducted on "WTA Championships 2013" tennis tournament. The purpose of this study is to measure brand equity on "WTA Championships 2013" tennis tournament and to analyze "Audience-based brand equity" and adapt it to the sports marketing literature. Besides, this study contributes to the scale validation as well as understanding of the benefits of brand equity on sports industry. Also by considering the emotional behaviours displayed by the audiences in sports events, it will provide important clues regarding the sports marketing (Madrigal, 2003; Biscaia et al., 2012). Therefore the result of this study has importance because of its contribution to the sports marketing literature.

\subsection{Scope and Limitations of Research}

Scope of the research includes identification of intentionally or unintentionally using of brand loyalty of audiences in "WTA Championships 2013" tennis tournament and includes how and wherein they perceive the brand and the reasons of why they prefer it.

As stated on its purpose, the research is very important in terms of offering benefits to audience more than they really want, meeting the changing audience demands by the brand, being the relationship between brand's quality and its price demand credible in the eyes of audience, being the brand like a trusted friend and well-understood what it means for the consumers, importance of brand performance as the preferred brand by consumers and audience-based brand equity. Research includes some limitations:

- The elements of time and cost constitute the most important limitation of research. It can be said that the audience behaviours are different reaction-oriented at different times. However, this research has been conducted in a six-day period. It can be also designed in a way to cover a wider time frame.

- Brand equity in the literature is examined as business based, financial and/or customer based. In this study, the business size and financial aspects have not been addressed and the issue is only discussed as customer based. This situation constitutes also another limitation of the research.

- This study was carried out in "WTA Championships 2013" for the tennis audiences and audiences from other branches were excluded from the scope. Furthermore, the research was carried out in only tennis tournament held in Istanbul. Recruitment of a specific group of audience to the research constitutes a further limitation of this study.

- The research tried to be focused on audience-based brand equity related to sports marketing. Therefore, it can be said that this study has a limitation in terms of results containing only audience-based brand equity for the sports marketing. 


\subsection{Research Model}

In the model developed for the purpose of research, relationships between variables will be examined and based on the findings, validity of the brand equity structure of audience-based brand equity will be determined. In the research model, due to the identification of relationships between variables descriptive research model, where the causal relationships between variables, causal research model was used. Descriptive researches indicate the interest and level of interest level or the association between two variables. However, by descriptive researches, it is not possible to identify cause and effect relationship (Nakip, 2006: 129). Causal research model is aimed at determining cause and effect relationship between the variables (Kurtuluş, 2004: 254). Nevertheless, the relationships in research model are the causal rather than an absolute causality. It has been determined with the related researches, consumer-based brand equity expressed as audience-based in this study consist of four-dimension and there are interdimensional relationships (Washburn and Plank, 2002: 56; Kim et al., 2003: 339; Pappu et al., 2005: 147). Research model created in order to verify the validity of dimension forming the consumer-based brand equity that is shown in Figure 2.

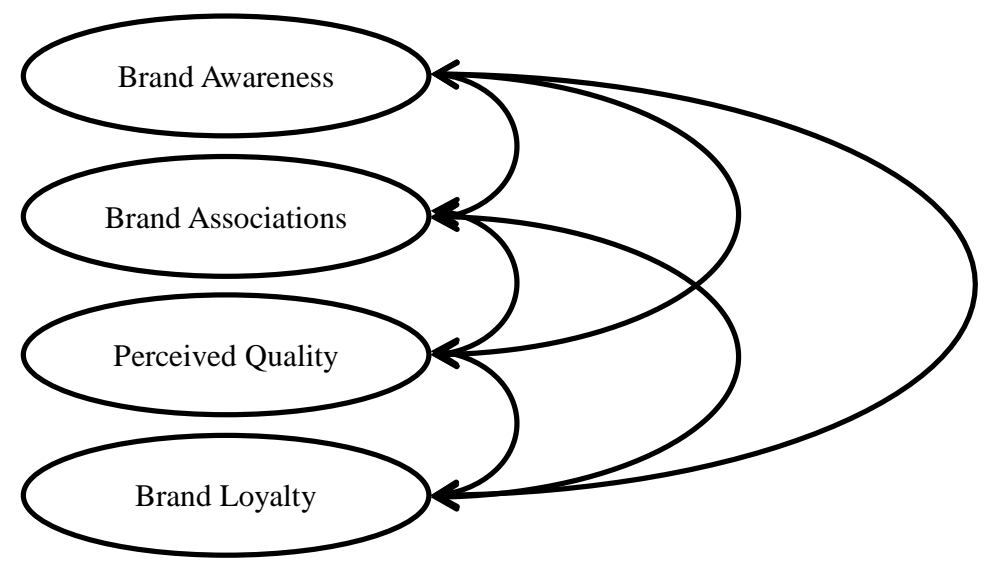

Figure 2. Research model

Source: Pappu et al. (2005), 147.

While examining the figure, it is seen that the conceptual structure of audience-based brand equity consist of four-dimension. These dimensions are brand awareness, brand associations, perceived quality and brand loyalty. Based on the presence of the relationship between them, the connection with each other is shown in figure. Arising of brand equity can be possible with wholly handling four dimensions shown in the figure. Because four dimensions which create brand equity behave interdependently. For this reason, interdimensional relationship is shown by a bidirectional arrow.

Research model also brings out research question. In this context, research question is formed as "Is recommended model appropriate for audience-based brand equity?" According to model, it has been proposed the hypothesis under the purpose of research "H1: the suggested model for the audience-based brand equity is suitable". This hypothesis will be tested by analysis to be performed.

\subsection{Sample Selection and Sample Size}

The universe of research is constituted by the audiences that have already participated in WTA Championship Istanbul 2013 was held between 22-27 October 2013 in Sinan Erdem Sports Hall Istanbul. The research sample unit is designated by audiences. During the tournament, 69.983 audiences have taken place on tribunes. In order to determine a sample in the study, considering the total number of audience that attended the tournament in the past, was determined a prospective sample. Considering that approximately 70.000 spectators attended the tournament in previous years, with 5\% of an acceptable error, it has been determined the requirement to be reached at least 382 people at $95 \%$ of confidence level and 659 people at $99 \%$ of confidence level (The Survey System, 2014). In order to conduct the research at $99 \%$ of confidence level, was made an interview with audiences during the six-days of competitions of the tournament is being taken place. In order to reach the desired number of people at desired confidence level, every day 120 questionnaires has been filled by randomly selected audiences. Thus, 720 questionnaires were obtained at the end of the data collection process.

Validity and reliability of the scales used in this research has been proven by different studies previously 
conducted. However, some expressions have been added to such scale because of field differences which are subject to research. Therefore, the reliability and validity of the scale had to be retested through a pilot research. For the pilot research, one of the non-random sample methods "convenience sampling" is used (Yükselen, 2008; Yükselen, 2006: 47; Altunıșik et al., 2001: 73). It is clear that one of the random sampling method must be used in virtue of making high-level analysis and testing a model, in the main research. One of the random sampling method "simple random sampling" is used in the main research (Nakip, 2006: 215-216).

\subsection{Methods and Tool of Data Collection}

In the research, the survey method was used as a method of data collection. Making face to face interviews with the participants in the tournament WTA Championships Istanbul 2013 that was held between 22 to 27 October 2013, the data needed for analysis was obtained by the survey method. In this study, multi-dimensional consumer-based brand equity that has been developed by Yoo et al. (2000) was used by translating into Turkish to determine the dimension of audience-based brand equity of the participants in WTA Championships Istanbul 2013. In the original scale there are six judgements which measure the size of the perceived quality. Three of these judgements were excluded from the scale used in the study due to being unavailability for research. The questionnaire that was prepared to measure audience-based brand equity, composed of two parts. In the first section there were four questions containing demographic information of the participants. In the second section there was an element forming audience-based brand equity, measuring four-dimension and a scale containing 12 judgements, in which the participants were asked to what extent they participate in each statement, using a 5 -point Likert scale. Scales were represented in the range of " $5=\mathrm{I}$ absolutely agree and $1=\mathrm{I}$ strongly disagree".

On the scale there are; three judgements measuring perceived quality of the brand, three judgements measuring brand loyalty, three judgements measuring brand awareness and three judgements measuring brand associations. In order to get opinions on issues such as intelligibility, scope and length of the judiciary, a pre-test was conducted with 30 students by using the convenience sampling method. The questionnaire was revised for necessary changes, finalized and applied accordingly.

\subsection{Data Analysis Method}

Research was carried out in two stages. First of all a pre-test was done to test the suitability of area for scale, to revise/remove incomprehensible expressions and to test the reliability. In the second stage, confirmatory factor analysis, multiple-group confirmatory factor analysis and structural equation modeling studies were used.

Analyzes were initiated by calculating alpha coefficients of internal consistency of the variables (Cronbach's Alpha) that forms the factors. The number of dimensions that forms audience-based brand equity was determined by exploratory factor analysis. With confirmatory factor analysis, research hypothesis was tested by determining the validity and reliability of conceptual structure of consumer-based brand equity. Exploratory factor analysis is a multivariate analysis method used for determining the number of dimensions forming the conceptual structure. The exploratory factor analysis provides information for the number of dimension in the proposed model, does not provide information for the validity and reliability of dimension. It is possible to determine validity and reliability in the model with a confirmatory factor analysis (Churchill, 1979: 69-70). Confirmatory factor analysis (CFA) is a statistical analysis method used for testing the validity and reliability of scales to measure the models developed based on the theory (MacCallum and Austin, 2000: 208). Measurement model was estimated using the covariance input matrix. Covariance input matrix is used for testing the theory and comprasion of different universe and samples (Hair et al., 1998: 603). In the analysis, maximum likelihood estimation method was used. Maximum likelihood estimation method is one of the most frequently used on confirmatory factor analysis (Chou and Bentler, 1995: 38). Maximum likelihood estimation method which requires multiple-distribution assumption provides good-unbaised estimations for non-distorted data and extremely non-flattened data (distortion less than 2, flatness less than 7) (Bollen, 1998: 266-267; Hoyle and Panter, 1995: 163). Research data were analyzed through SPSS statistical packaged software and LISREL structural equation modeling.

\section{Findings}

During the research at first, internal consistency of audience-based brand equity was determined. In order to test internal consistency developed for measuring audience-based brand equity that was used alpha coefficient (Cronbach's Alpha). As a result of analysis, to say that the scale is reliable the values of alpha coefficient should be higher than 0.70 (Hair et al., 1998). It can be said that the tournament had been organized with the name "WTA Championships Istanbul 2013" is a brand. From this point, alpha values of audience-based brand equity of the "WTA Championships Istanbul 2013" that are given in Table 1. 
Alpha coefficients of audience-based brand equity of "WTA Championships Istanbul 2013" are estimated; perceived quality 0.89 , brand associations 0.81 , brand loyalty 0.78 and brand awareness 0.73 . It can be said that the scale used for analysis is reliable because of alpha coefficients of the value size of "WTA Championships Istanbul 2013" brand is higher than 0.70 .

Exploratory factor analysis has been conducted to determine the dimensions (perceived quality, brand loyalty, brand awareness and brand associations) of audience-based brand equity "WTA Championships Istanbul 2013". In factor analysis, the principal components and varimax rotation methods were used and while determining the number of factors, the factors with eigenvalues greater than 1 were taken into consideration. In order to test the data used in factor analysis whether it is appropriate, Kaiser-Meyer-Olkin (KMO) test and Bartlett's Test of Sphericity were done. KMO is a test that indicates the validity of factor analysis. This test relates the sample size and aims to measure the efficiency of sampling. KMO over $60 \%$ is required to be applied the factor analysis (Nakip, 2003:409). The result of KMO in this research is estimated 73.8\%. Since the KMO test results are above $60 \%$, it can be said the data-set is suitable for the factor analysis.

Bartlett's Test of Sphericity examines whether the correlation matrix is an identity matrix, which would indicate that the factor model is inappropriate (Hair et al., 1998: 88). In case of the significance level of test is less than 0.05 , indicates that the correlation matrix is not identity matrix and thus there are relationships between the variables. In this study, Bartlett's Test of Sphericity significance levels $(p=0,000)$ are increased. The results of the correlation matrix is not the identity matrix and it illustrates the relationships between the variables. Exploratory factor analysis results are shown in Table 1.

Table 1. Exploratory factor analysis results

\begin{tabular}{|c|c|c|c|c|}
\hline & Brand Associations & Brand Loyalty & Perceived Quality & Brand Awareness \\
\hline BAS2 & 0,84 & & & \\
\hline BAS1 & 0,81 & & & \\
\hline BAS3 & 0,72 & & & \\
\hline BL3 & & 0,86 & & \\
\hline BL1 & & 0,75 & & \\
\hline BL2 & & 0,71 & & \\
\hline PQ2 & & & 0,82 & \\
\hline PQ3 & & & 0,78 & \\
\hline PQ1 & & & 0,77 & \\
\hline BAW3 & & & & 0,83 \\
\hline BAW2 & & & & 0,77 \\
\hline BAW1 & & & & 0,75 \\
\hline Disclosed variance $\%$ & 19,74 & 17,92 & 16,67 & 15,89 \\
\hline Alpha & 0,89 & 0,81 & 0,78 & 0,73 \\
\hline Total disclosed variance $\%$ & 70,22 & & & \\
\hline KMO & 73,8 & & & \\
\hline Bartlett Test & $798,65 \mathrm{df}=68 \mathrm{p}=, 000$ & & & \\
\hline Factor Weights & $>0,50$ & & & \\
\hline
\end{tabular}

Note. BAS=Perceived Quality, BL=Brand Loyalty, $\mathrm{PQ}=$ Brand Associations, $\mathrm{B} A W=$ Brand Awareness.

While examining Table 1, for the scales used in the research, four factors with eigenvalues greater than 1; $70,22 \%$ of the total variance was explained as $19,74 \%$ of variance on perceived quality and $17,92 \%$ for brand loyalty, $16,67 \%$ for brand associations and finally $15,89 \%$ for brand awareness. Perceived quality, brand loyalty, brand awareness and brand association have been determined as the dimensions forming audience-based brand equity. Since the description of "the highest variance of perceived quality" it has emerged as it is an important factor in research. 
In order to verify the validity of dimensions (brand awareness, brand association, perceived quality and brand loyalty) that forms audience-based brand equity determined by exploratory factor analysis, was coducted a confirmatory factor analysis through LISREL which is a packaged software. Prior to be evaluated the results of confirmatory factor analysis, it is required that the estimated values whether exceeds the theoretical limits (offending estimate). Negative error variance, error variance statistically insignificant and correlation values greater than 1 that lead to exceed the theoretical limits (Hair et al., 1998: 582). As a result of exmination, no value has been determined that exceed the theorical limits. Fit Index related to confirmatory factor analysis is shown in Table 2.

As it is seen on Table 2, Chi square $\left(\chi^{2}\right)$ value and statistical significance level are estimated on 45 degree of freedom, 57,562 $(\mathrm{p}=0,067)$. As a result of Chi square $\left(\chi^{2}\right)$ statistic test, the hypothesis H1 (H1: the model proposed for audience-based brand equity is suitable) developed in the framework of research model has been accepted for "WTA Championships Istanbul 2013". In other words, the model is consisting of four dimensions (brand awareness, brand associations, perceived quality and brand loyalty) forming audience-based brand equity that is a suitable model for "WTA Championships Istanbul 2013".

Table 2. Goodness of Fit Index (GFI) of confirmatory factor analysis results

\begin{tabular}{lcc}
\hline & $\begin{array}{c}\text { Acceptable Levels of Goodness } \\
\text { of Fit Measures* }\end{array}$ & $\begin{array}{c}\text { Results from the data of 'WTA } \\
\text { Championships Istanbul 2013' }\end{array}$ \\
\hline Goodness of Fit Index (GFI) & $\geq 0,95$ & 0,967 \\
Adjusted Goodness of Fit Index (AGFI) & $\geq 0,90$ & 0,919 \\
Squared Error Estimation Root Mean Square Error of & $<0,05$ & 0,031 \\
Approximation (RMSEA) & $\geq 0,95$ & 0,962 \\
Tucker Levis Index (TLI) & $\geq 0,95$ & 0,968 \\
Increasing Fit Index (IFI) & $\geq 0,95$ & 0,974 \\
Comparative Fit Index (CFI) & $>0,05$ & 0,067 \\
Significance level (P) & & 57,562 \\
Chi Square $(\chi 2)$ & & 45 \\
Degree of Freedom (df) & & 45 \\
\hline
\end{tabular}

* Source. Schumacker and Lomax, 2014: 82.

While being examined other goodness of fit index in Table 2; Goodness of Fit Index (GFI) value 0,967 is higher than proposed one GFI $\geqslant 0,95$. Goodness of Fit Index (GFI) value indicates that the model proposed for "WTA Championships Istanbul 2013" is suitable. Adjusted Goodness of Fit Index (AGFI) value 0,919 is higher than proposed one AGFI $\geqslant 0,90$. Root Mean Square Error of Approximation (RMSEA) value 0,031 is smaller than proposed one RMSEA $<0,05$. Tucker Levis Index (TLI) value 0,962 is higher than proposed one TLI $\geqslant 0,95$. Increasing Fit Index (IFI) value is higher than IFI $\geqslant 0,95$. Comparative Fit Index (CFI) value is higher than CFI $\geqslant 0,95$.

Table 3. Standardized parameter estimations

\begin{tabular}{|c|c|c|c|}
\hline DIMENSIONS AND VARIABLES & $\begin{array}{l}\text { Standardized } \\
\text { regression coefficient }\end{array}$ & $\begin{array}{l}\text { Standard } \\
\text { error }\end{array}$ & $\begin{array}{c}\text { t- } \\
\text { Value }\end{array}$ \\
\hline \multicolumn{4}{|l|}{ BRAND AWARENESS (BAW) } \\
\hline BAW3: I know “WTA Championships Istanbul 2013” brand. & $0,71 *$ & - & - \\
\hline $\begin{array}{l}\text { BAW2: Compared to other tournaments, I distinguish "WTA Championships } \\
\text { Istanbul 2013" }\end{array}$ & $0,79^{*}$ & 0,72 & 10,67 \\
\hline BAW1: I realize “WTA Championships Istanbul 2013” everywhere. & $0,83^{*}$ & 0,69 & 9,84 \\
\hline
\end{tabular}




\begin{tabular}{|c|c|c|c|}
\hline \multicolumn{4}{|l|}{ BRAND ASSOCIATIONS (BAS) } \\
\hline $\begin{array}{l}\text { BAS2: Features of the brand "WTA Championships Istanbul 2013" immediately } \\
\text { come to my mind. }\end{array}$ & $0,87^{*}$ & - & - \\
\hline BAS1: I am quickly reminded of "WTA Championships Istanbul 2013" logo. & $0,76^{*}$ & 0,82 & 10,11 \\
\hline BAS3: I am not forced to imagine "WTA Championships Istanbul 2013" brand. & $0,82 *$ & 0,89 & 9,74 \\
\hline \multicolumn{4}{|l|}{ PERCEIVED QUALITY (PQ) } \\
\hline PQ2: "WTA Championships Istanbul 2013" brand represents quality. & $0,83^{*}$ & - & - \\
\hline PQ3: "WTA Championships Istanbul 2013" brand gives pleasure. & $0,72 *$ & 0,74 & 9,87 \\
\hline PQ1: "WTA Championships Istanbul 2013" brand is attractive. & $0,74 *$ & 0,71 & 9,73 \\
\hline \multicolumn{4}{|l|}{ BRAND LOYALTY (BL) } \\
\hline BL3: My first choice is "WTA Championships Istanbul 2013" & $0,75^{*}$ & - & - \\
\hline BL1: I constantly follow “WTA Championships Istanbul 2013" brand. & $0,71^{*}$ & 0,79 & 10,09 \\
\hline $\begin{array}{l}\text { BL2: Compared to other tournaments, I prefer "WTA Championships Istanbul } \\
\text { 2013". }\end{array}$ & $0,77^{*}$ & 0,74 & 10,18 \\
\hline
\end{tabular}

${ }^{\mathrm{a}}$ The regression coefficient is equal to $1, *$ Coefficients are statistically significant $\mathrm{p}<0,01$.

As a result of Chi square $\left(\chi^{2}\right)$ statistic test, the model $p=0,05$ proposefor "WTA Championships Istanbul 2013" has been accepted on significance level. Furthermore, also other goodness of fit index indicate that the model proposed for "WTA Championships Istanbul 2013" is correspondent with observed data. Taking a non-zero value of standardized residual covariance for the brand "WTA Championships Istanbul 2013" and in consequence of getting values lower than $\pm 2,58$ that indicate the proposed model for audience-based brand equity is accordant with the collected data for the "WTA Championships Istanbul 2013". Following being determined the research model is correspondent with observed data for the brand "WTA Championships Istanbul 2013", t-statistical values verify whether the parametres estimated by confirmatory factor analysis, standardized regression coefficients and standard errors are non-zero is shown in Table 3.

While examining Table 3, it is seen that the variables of four dimensions forming audience-based brand equity are under the factors they belong to "WTA Championships Istanbul 2013" brand. Standardized regression coefficients of variables are at high level and of t-statistical values are greater than $\pm 2,58$. Thus, standardized regression coefficients of variables under the factors are non-zero and statistically $(p<0,01)$ significant. In research model, correlation between the four dimensions forming audience-based brand equity is shown with dual sided arrow. Correlation coefficients are indicated in Table 4.

Table 4. CFA Results-Reliability of Dimensions and Inter-factor Correlation Matrix

\begin{tabular}{|c|c|c|c|c|c|c|}
\hline & Reliability & $\begin{array}{c}\text { Square root of } \\
\text { disclosed variance }\end{array}$ & BAW & BAS & PQ & BL \\
\hline BAW & 0,79 & 0,75 & 1 & & & \\
\hline BAS & 0,85 & 0,81 & 0,30 & 1 & & \\
\hline PQ & 0,82 & 0,76 & 0,43 & 0,38 & 1 & \\
\hline BL & 0,86 & 0,83 & 0,25 & 0,19 & 0,31 & 1 \\
\hline
\end{tabular}

Note. BAS=Perceived Quality, BL=Brand Loyalty, PQ=Brand Associations, BAW=Brand Awareness. Correlation values are statistically significant $(\mathrm{p}<0,05)$.

While examining Table 4, Inter-factors correlation coefficient for the brand "WTA Championships Istanbul 2013" was non-zero and gave statistically significant results $(\mathrm{p}<0,05)$ when the relationship between factors were examined; the highest correlation $(\rho=0,43)$ was between the brand awareness and perceived quality size. The findings obtained in consequence of analysis that supports the existence of relationships forming audience-based brand equity. In order to decide whether the measurement model is suitable, it is required to determine the reliability of dimensions in the model (Churchill, 1979: 66). The reliability is internal consistency of the 
variables that forms the structure (Hair et al., 1998: 584-612).

It is required to ensure dissociation validity of dimensions in the model to be validated the structure in the research model. Dissociation validity can be determined by comparing the interdimensional correlation coefficients with the variance value of each dimension. In case of the value of square root of variance of each dimension is greater than correlation value, this shows dissociation validity of dimensions (Fornell and Lacker, 1981:46). Therefore, in Table 4 it is shown square root values of the variance. It is seen that the value of square root of variance of each dimension for the brand "WTA Championships Istanbul 2013" is greater than correlation values.

Reliability levels of dimensions in model should be higher than 0,70 to determine reliability of measurement model (Hair et al., 1998: 612). Estimated reliability levels and levels of disclosed variance are indicated on Table 4. Estimated reliability levels of dimensions that form audience-based brand equity for the brand "WTA Championships Istanbul 2013" are higher than recommended one 0,70. These results support that quaternary structure that forms audience-based brand equity and exist in research model is valid and reliable.

\section{Result and Discussion}

Intangible assets of the Business are basis of brand equity. Brand equity components are grouped under two topics, consumer behaviours and consumer perceptions. While the brand equity components for consumer perception is composed of brand awareness, brand associations and perceived quality, components for consumer behaviour is composed of brand loyalty, brand preference and willingness to pay higher price (Kim et al., 2003: 336). Mostly the researchers in the studies prefer to handle it both perceptual and behavioural dimensions. If these components are well-managed, it is expected to add value to the product, increase customer satisfaction and provide many benefits to the Business (Tuominenn, 1999: 80).

Aaker's (1991) proposed model is a basis for measurement of consumer-based brand equity and has been widely used in subsequent studies. In this model Aaker (1991) has reviewed consumer-based brand equity in four dimensions; brand loyalty, brand awareness, perceived quality and brand associations. In these four dimensions Casey (2003) and Tolba (2006) have added a fifth-dimension as the brand peformance and measured their studies with this fifth- dimension.

In the research, using multi-dimensional consumer-based brand equity scale that has been developed by Yoo et al. (2000), the conceptual structure for consumer-based brand equity proposed by Aaker (1991) was tested by adapting it to the relevant area. As a result of the analysis made on the basis of the findings obtained, it can be said that the audience-based brand equity is composed of four dimensions and there are interdimensional relationships. By research conducted in different countries with different product categories, adapting the scale of audience-based brand equity to the sports marketing to be able to measure brand equity, it was determined that the scale may be used with the name "Audience-based brand equity" so that is thought to contribute to the sports marketing literature.

The main purpose of sports organizations is to promote all opportunities offered by the sports organizations and creating services to ensure a sports product to be purchased according to demands of consumers. Within this context, audience-based brand equity may be considered as a tool to realize this aim. Therefore, it is sought to contribute to the literature by testing audience-based brand equity.

While examining findings obtained in research, it is seen that perceived quality dimension describes the highest variance. This finding shows that perceived quality dimension is an important factor in the research. High quality perception of sports product consumer, as in every branch, reveals itself in branch of tennis. Because sports product consumers want to take pleasure in competition they watch and in response to this promise of competitions they make purchasing. Quality perception of sports product consumer may be associated with other complementary elements of the organization. This usually happens when the sports product consumer is having fun while watching a sport event as well as socializing and wants to combine different experiences during the event he/she is participating (Tüfekci, 2011: 17-18).

It can be said that research results contribute to sports marketing literature. Audience-based brand equity's being tackled slightly in sports marketing literature supports this expression. Gladden and Milne (1999) evaluated the importance of brand equity in professional sports. Cornwell et al. (2001) tackled sponsorship effect on brand equity within the context of managers. Bauer et al. (2005) explained consumer-based brand equity in team sports sector. In the research they carried out, they searched the effect of consumer-based brand equity on economic success of sport teams. Ross (2006) created a cognitive roof in order to make audience-based brand equity understand. Tong and Hawley (2009) measured consumer-based brand equity in sportswear bazaar in China. 
Gladden et al. (2001) are focused on professional sports teams' building brand equity. This research, as distinct from other studies carried out in this area, reveals that audience-based brand equity can be a model which can be tackled as part of sport marketing. On that sense, it contributes to concerned literature.

In this study, a valid model for the audience-based brand equity is presented. It is assumed that this model including brand associations, brand satisfaction, brand confidence and brand loyalty that contributes to the researches for marketing and brand management of sport teams and organizations. Furthermore, it can be investigated the proposed model whether is valid in other branch of sports and the interdimensional relationships whether differ by other branches.

\section{References}

Aaker, D. A. (1990). Brand Extensions: The Good, the Bad and the Ugly. Journal of Management Review, 31(4), $1-8$.

Aaker, D. A. (1991). Managing Brand Equity. N.Y.: Free Press.

Aaker, D. A. (1992). The Value of Brand Equity. Journal of Business Strategy, 13(4), 27-32. http://dx.doi.org/10.1108/eb039503

Aaker, D. A. (1996). Measuring brand equity across products and markets. California Management Review, 38(3), 102-120. http://dx.doi.org/10.2307/41165845

Aaker, D. A. (2009). Güçlü Markalar Yaratmak. Çev: Erdem Demir, İstanbul, MediaCat.

Agarwal, M. K., \& Rao, V. R. (1996). An empirical comparison of consumer based measures of brand equity. Marketing Letters, 7(3), 237-247. http://dx.doi.org/10.1007/BF00435740

Altunışı, R., Coşkun, R., Yıldırım, E., \& Bayraktaroğlu, S. (2001). Sosyal bilimlerde araştırma yöntemleri: SPSS uygulamall. Adapazarı: Sakarya Kitabevi.

Atılgan, E. (2005). Marka değeri belirleyicilerinin uluslararası analizi. Yayınlanmamış doktora tezi, Akdeniz Üniversitesi Sosyal Bilimler Enstitüsü İşletme Anabilim Dalı, Antalya.

Aziz, N. A., \& Yasin, N. M. (2010). Analyzing the brand equity and resonance of banking services: Malaysian consumer perspective. International Journal of Marketing Studies, 2(2), 180-189. http://dx.doi.org/10.5539/ijms.v2n2p180

Bauer, H. H., Sauer, N. E., \& Schmitt, P. (2005). Customer-based brand equity in the team sport industry: Operationalization and impact on the economic success of sport teams. European Journal of Marketing, 39(5/6), 496-513. http://dx.doi.org/10.1108/03090560510590683

Bauer, H. H., Stokburger-Sauer, N. E., \& Exler, S. (2008). Brand Image and Fan Loyalty in Professional Team Sport: A Refined Model and Empirical Assessment. Journal of Sport Management, 22, 205-222.

Biscaia, R., Correia, A., Rosado, A., Maroco, J., \& Ross, S. (2012). The effects of emotions on football spectators' satisfaction and behavioral intentions. European Sport Management Quarterly, 12(3), 227-242. http://dx.doi.org/10.1080/16184742.2012.679949

Biscaia, R., Correia, A., Ross, S., Rosado, A., \& Maroco, J. (2013). Spectator-based brand equity in professional soccer. Sport Marketing Quarterly, 22(1), 20-32.

Bollen, K. A. (1989). Structural Equations with Latent Variables. New York, USA: John Wiley \& Sons Inc.

Broyles, S. A., Leingpibul, T., Ross, R. H., \& Foster, B. M. (2010). Brand equity's antecedent/consequence relationships in cross-cultural settings. Journal of Product \& Brand Management, 19(3), 159-169. http://dx.doi.org/10.1108/10610421011046148

Buil, I., de Chernatony, L., \& Martinez, E. (2008). A Cross-National 'Validation of the Consumer-Based Brand Equity Scale. Journal of Product \& Brand Management, 17(6), 384-392. http://dx.doi.org/10.1108/10610420810904121

Casey, R. (2003). The Effect of Brand Equity on Brand Knowledge: An Empirical and Comparative Analysis. Nava Southeastern University, USA: Philosopy of Doctor.

Chattopadhyay, T., Shivani, S., \& Krishnan, M. (2009). Determinants of brand equity-A blue print for building strong brand: A study of automobile segment in India. African Journal of Marketing Management, 1(4), 109-121.

Chaudhuri, A., \& Holbrook, M. B. (2001). The Chain of Effects from Brand Trust and Brand Affect to Brand 
Performance: The Role of Brand Loyalty. The Journal of Marketing, 65(2), 81-93. http://dx.doi.org/10.1509/jmkg.65.2.81.18255

Chou, C. P., \& Bentler, P. M. (1995). Estimates and Tests in Structural Equation Modeling. In Hoyle, R. H. (Ed.), Structural Equation Modelling: Concepts, Issues, and Applications (pp. 37-54), London, United Kingdom: Sage Publications Inc.

Churchill, G. A. (1979). A Paradigm for Developing Better Measures of Marketing Constructs. Journal of Marketing Research, 16(1), 64-73. http://dx.doi.org/10.2307/3150876

Cobb-Walgren, C. J., Ruble, C. A., \& Donthu, N. (1995). Brand equity, brand preference, and purchase intent. Journal of Advertising, 24(3), 25-40. http://dx.doi.org/10.1080/00913367.1995.10673481

Cornwell, T. B., Roy, D. P., \& Roy, D. P. (2001). Exploring managers' perceptions of the impact of sponsorship on brand equity. Journal of Advertising, 30(2), 41-51. http://dx.doi.org/10.1080/00913367.2001.10673636

Dick, S. A., \& Basu, K. (1994). Customer Loyalty: Toward Integrated Conceptual Framework. Journal of Academy of Marketing, 22, 99-113. http://dx.doi.org/10.1177/0092070394222001

Dyson, P., Farr, A., \& Hollis, N. S. (1996). Understanding, measuring, andusingbrandequity. Journal of Advertising Research, 36(6), 9-21. http://dx.doi.org/10.1108/17566691011090044

Eagle, L., Kitchen, P. J., Rose, L., \& Moyle, B. (2003). Brand equity and brand vulnerability: The impact of gray marketing/paralel importing on brand equity and values. European Journal of Marketing, 37(10), 1332-1349. http://dx.doi.org/10.1108/03090560310487130

Erdem, T., \& Swait, J. (1998). Brand equity as a signaling phenomenon. Journal of Consumer Psychology, 7(2), 131-157. http://dx.doi.org/10.1207/s15327663jcp0702_02

Erdem, T., Swait, J., Broniarczyk, S., Chakravarti, D., Kapferer, J. N., Keane, M., Roberts, J., Steenkamp, J. B. E. M., \& Zettelmeyer, F. (1999). Brand Equity, Consumer Learning and Choice. Marketing Letters, 10(3), 301-318. http://dx.doi.org/10.1023/A:1008135224357

Farquhar, P. H. (1989). Managing brand equity. Marketing Research, 1(September), 24-33.

Farquhar, P. H. (1990). Managing brand equity. Journal of Advertising Research, 30(4), RC7-RC12.

Filo, K., Funk, D. C., \& Alexandris, K. (2008). Exploring the Role of Brand Trust on the Relationship between Brand Associations and Brand Loyalty in Sport and Fitness. International Journal of Sport Marketing and Management, 3, 39-57. http://dx.doi.org/10.1504/IJSMM.2008.015960

Fornell, C., \& Larcker, D. F. (1981). Evaluating Structural Equation Models with Unobservable Variables and Measurement Error: Algebra and Statistics. Journal of Marketing Research, 18, 39-50. http://dx.doi.org/10.2307/3151312

Fournier, S. \& Yao, J. L. (1997). Reviving Brand Loyalty: A Reconceptualization within the Framework of Consumer-Brand Relationships. International Journal of Research in Marketing, 14, 451-472. http://dx.doi.org/10.1016/S0167-8116(97)00021-9

Garbarino, E., \& Johnson, M. S. (1999). The Different Roles of Satisfaction, Trust, and Commitment in Customer Relationships. The Journal of Marketing, 63(2), 70-87. http://www.jstor.org/stable/1251946

Gladden, J. M., \& Funk, D. C. (2002). Developing an Understanding of Brand Associations in Team Sport: Empirical Evidence from Consumers of Professional Sport. Journal of Sport Management, 16, 54-58.

Gladden, J. M., \& Milne, G. R. (1999). Examining the importance of brand equity in professional sports. Sport Marketing Quarterly, 8, 21-30.

Gladden, J. M., Irwin, R. L., \& Sutton, W. A. (2001). Managing North American major professional sport teams in the new millennium: A focus on building brand equity. Journal of Sport Management, 15(4), 297-317.

Gladden, J. M., Milne, G. R., \& Sutton, W. A. (1998). A Conceptual Framework for Assessing Brand Equity in Division I College Athletics. Journal of Sport Management, 12(1), 1-19.

Hair, J. F., Anderson, R. E., Tatham, R. L., \& Black, W. C. (1998). Multivariate Data Analysis (5th ed.). New Jersey, USA: Prentice-Hall Inc.

Hilgenkamp, H., \& Shanteau, J. (2010). Functional measurement analysis of brand equity: does brand name affect perceptions of quality? Psicológica, 31(3), 561-575.

Hong, G., Macdonald, M., Fujimoto, J., \& Yoon, C. (2005). Motivation for Japanese baseball fan's interest in 
Major League Baseball. International Journal of Sport Management and Marketing, 1(1/2), 141-154. http://dx.doi.org/10.1504/IJSMM.2005.007126

Hoyle, R. H., \& Panter, A. T. (1995). Writing About Structural Equation Models. In Hoyle, R. H. (Ed.), Structural Equation Modelling: Concepts, Issues, and Applications (pp. 158-176). London, United Kingdom, Sage Publications Inc.

Hsieh, M. H. (2004). Measuring Global Brand Equity Using Cross-National Survey Data. Journal of International Marketing, 12(2), 28-57. http://dx.doi.org/10.1509/jimk.12.2.28.32897

Jacobson, R., \& Aaker, D. A. (1987). The Strategic Role of Product Quality. Journal of Marketing, 51(4) 31-44. http://dx.doi.org/10.2307/1251246

Jacoby, J., \& Kyner, D. B. (1973). Brand Loyalty Versus Repeat Purchasing Behavior. Journal of Marketing Research, 10(1), 1-9. http://dx.doi.org/10.2307/3149402

Javadein, S. R. S., Khaniari, A., \& Estiri, M. (2008). Customer Loyalty in the Sport Services Industry: The Role of Service Quality, Customer Satisfaction Commitment and Trust. International Journal of Human Science, $5(2), 1-19$.

Kabadayi, E. T., \& Aygün, I. (2007). Determinants of Brand Loyalty and the Link between Brand Loyalty and Price Tolerance. Bogazici Journal of Economics and Administrative Sciences, 21(1-2), 21-35.

Kapferer, J. N. (2004). The new strategic brand management: Creating and sustaining brand equity long term. London, UK: Kogan Page.

Kayaman, R., \& Arasli, H. (2007). Customer-based brand equity: evidence from the hotel industry. Managing Service Quality, 17(1), 92-109. http://dx.doi.org/10.1108/09604520710720692

Keller, K. L. (1993). Conceptualizing, measuring, and managing customer-based brand equity. Journal of Marketing, 57(1), 1-22. http://www.jstor.org/stable/1252054

Keller, K. L., \& Lehmann, D. R., (2006). Brands and branding: Research findings and future priorities. Marketing Science, 25(6), 740-759. http://dx.doi.org/10.1287/mksc.1050.0153

Kim, H., \& Kim, W. G. (2005). The relationship between brand equity and firms' performance in luxury hotels and chain restaurants. Tourism Management, 26, 549-560. http://dx.doi.org/10.1016/j.tourman.2004.03.010

Kim, H., Kim, W. G., \& An, J. A. (2003). The effect of consumer-based brand equity on firms' financial performance. The Journal of Consumer Marketing, 20(4), 335-351. http://dx.doi.org/10.1108/07363760310483694

Kim, J., Morris, J. D., \& Swait, J. (2008). Antecedents of True Brand Loyalty, Journal of Advertising, 37(2), 99-117. http://dx.doi.org/10.2753/JOA0091-3367370208

Kotler, P., \& Armstrong, M. G. (1989). Business-Economics. Prentice-Hall.

Kurtuluş, K. (2004). Pazarlama Araşstırmaları. Genişletilmiş Yedinci Basım, İstanbul: Literatür Yayıncılık Dağıtım Pazarlama San. Tic. Ltd. Şti.

Lassar, W., Mittal, B., \& Sharma, A. (1995). Measuring consumer-based brand equity. Journal of Consumer Marketing, 12(4), 4-11. http://dx.doi.org/10.1108/07363769510095270

Lau, G. T., \& Lee, S. H. (1999). Consumers' Trust in A Brand and The Link to Brand Loyalty. Journal of Market-Focused Management, 4(4), 341-370. http://dx.doi.org/10.1023/A:1009886520142

Lin, C. H., \& Kao, D. T. (2004). The Impacts of Country-of-Origin on Brand Equity. The Journal of American Academy of Business, 5(1/2), 37-40.

Low, S. G., \& Lamb, C. W. (2000). The Measurement and Dimensionality of Brand Associations. Journal of Product \& Brand Management, 9(6), 350-368. http://dx.doi.org/10.1108/10610420010356966

Maccallum, R. C., \& Austin, J. T. (2000). Applications of Structural Equation Modeling in Psychological Research. Annual Review of Psychology, 51(February), 201-226. http://dx.doi.org/10.1146/annurev.psych.51.1.201

MacKay, M. M., Romaniuk, J., \& Sharp, B. (1997). A typology of brand equity research. Proceedings of the Australia New Zealand Marketing Educators Conference (ANZMAC) (pp. 1146-1157). Department of Marketing, Monash University, Melbourne.

Madrigal, R. (2003). Investigating an evolving leisure experience: Antecedents and consequences of spectator 
affect during a live sporting event. Journal of Leisure Research, 35(1), 23-48.

Mullin, B., Hardy, S., \& Sutton, W. (2007). Sport marketing (3rd ed.). Champaign, IL: Human Kinetics.

Na, W. B., Marshall, R., \& Keller, K. L. (1999). Measuring brand power: validating a model for optimizing brand equity. Journal of Product \& Brand Management, 8(3), 170-184. http://dx.doi.org/10.1108/10610429910272439

Nakip, M. (2006). Pazarlama Araştırmaları Teknikler ve (SPSS Destekli) Uygulamaları. Ankara: Seçkin Yayıncilık.

Pappu, R., Quester, P. G., \& Cooksey, R. W. (2005). Consumer-based brand equity: improving the measurement-empirical evidence. Journal of Product \& Brand Management, 14(3), 143-154. http://dx.doi.org/10.1108/10610420510601012

Park, C. S., \& Srinivasan, V. (1994). A survey-based method for measuring and understanding brand equity and its extendibility. Journal of Marketing Research, 31, 271-288. http://dx.doi.org/10.2307/3152199

Rangaswamy, A., Burke, R. R., \& Oliva, T. A. (1993). Brand equity and the extendibility of brand names. International Journal of Research in Marketing, 10, 61-75. http://dx.doi.org/10.1016/0167-8116(93)90034-V

Rein, I., Kotler, P., \& Shields, B. (2007). The Elusive Fan. (Çev: Umut Esra Kaplan), Istanbul: MediaCat Kitapları.

Ross, S. D. (2006). A conceptual framework for understanding spectator-based brand equity. Journal of Sport Management, 20(1), 22.

Ross, S. D., James, J. D., \& Vargas, P. (2006). Development of a Scale to Measure Professional Sport Team Brand Associations. Journal of Sport Management, 20, 260-279.

Rundle-Thiele, S. R., \& Mackay, M. M. (2001). Assessing the Perfomance of Brand Loyalty Measures. Journal of Services Marketing, 15(7), 529-546. http://dx.doi.org/10.1108/EUM0000000006210

Schumacker, R. E., \& Lomax, R. G. (2004). Beginner's Guide to Structural Equation Modeling. New Jersey, USA: Lawrence Erlbaum Associates.

Simms, C. D., \& Trott, P. (2006). The perceptions of the BMW Mini brand: The importance of historical associations and the development of a model. Journal of Product and Brand Management, 15(4), 228-238. http://dx.doi.org/10.1108/10610420610679593

Simon, C. J., \& Sullivan, M.W. (1993). The measurement and determinants of brand equity: A financial approach. Marketing Science, 12(1), 28-52. http://dx.doi.org/10.1287/mksc.12.1.28

Solomon, R. M., \& Stuart, E. W. (2002). Marketing: Real People, Real Choice (2nd ed.). Prentice-Hall, Englewood Cliffs.

Swait, J., Erdem, T., Louviere, J., \& Dubelaar, C. (1993). The Equalization Price: A Measure of Consumer-Perceived Brand Equity. International Journal of Research in Marketing, 10(March), 23-45. http://dx.doi.org/10.1016/0167-8116(93)90031-S

Taylor, S. A., Celuch, K., \& Goodwin, S. (2004). The Importance of Brand Equity to Consumer Loyalty. Journal of Product \& Brand Management, 13(4), 217-227. http://dx.doi.org/10.1108/10610420410546934

The Survey System. (2014). Retrieved from http://www.surveysystem.com/sscalc.htm (14.01.2014)

Thode, S. F., \& Maskulka, J. M. (1998). Place-based marketing strategies, brand equity and vineyard valuation. The Journal of Product and Brand Management, 7(5), 379-399. http://dx.doi.org/10.1108/10610429810237673

Tolba, H. A. (2006). Integrating Customer Based Brand Equity with Brand Market Performance: An Empirical Invesigation of the U.S. Automotive Industry. Doctor of Philosophy, USA: George Washington University.

Tong, X., \& Hawley, J. M. (2009). Creating brand equity in the Chinese clothing market: The effect of selected marketing activities on brand equity dimensions. Journal of Fashion Marketing and Management, 13(4), 566-581. http://dx.doi.org/10.1108/13612020910991411

Tong, X., \& Hawley, J. M. (2009). Measuring customer-based brand equity: empirical evidence from the sportswear market in China. Journal of Product \& Brand Management, 18(4), 262-271. http://dx.doi.org/10.1108/10610420910972783 
Tüfekci, Ö. K. (2011). Spor Pazarlama Zekâsı: Marka Kimliği Yaratma Yeteneklerinin Analizi ve Batı Akdeniz Bölgesi Futbol Taban Birliklerinde Bir Uygulama. Süleyman Demirel Üniversitesi Sosyal Bilimler Enstitüsü İşletme Ana Bilim Dalı, Yayınlanmamış Doktora Tezi.

Tuominen, P. (1999). Managing Brand Equity. The Finnish Journal of Business, 48(1), 65-100.

Upshaw, L. B. (1995). Building brand identity: A strategy forsuccess in a hostile market place. New York: John Wiley \& Sons, Inc.

Washburn, J. H., \& Plank, R. E. (2002). Measuring Brand Equity: An Evaluation of a Consumer-Based Brand Equity Scale. Journal of Marketing Theory and Practice, 10(1), 46-62.

Winters, L. C. (1991). Brand equity measures: Some recent advances. Marketing Research, December, 70-73.

Wood, L. (2000). Brands and brand equity: definition and management. Management Decision, 38(9), 662-667. http://dx.doi.org/10.1108/00251740010379100

Yıldız, Y., Ay, C., \& Özbey, S. (2012). Futbol Takımlarında Tüketici Temelli Marka Değeri: Bir Model Önerisi. Ege Akademik Bakış, 12(Özel Sayı), 1-10.

Yoo, B., \& Donthu, N. (2001). Developing and validating a multidimensional consumer based brand equity scale. Journal of Business Research, 52(1), 1-14. http://dx.doi.org/10.1016/S0148-2963(99)00098-3

Yoo, B., Donthu, N., \& Lee, S. (2000). An Examination of Selected Marketing Mix Elements and Brand Equity. Academy of Marketing Science, 28(2), 195-211. http://dx.doi.org/10.1177/0092070300282002

Yükselen, C. (2006). Pazarlama araştırmaları. Ankara: Detay Yayıncılık.

Yükselen, C. (2008). Pazarlama Araştırmaları ve araştırma örnek olayları semineri notları. VI. Araştırma Yöntemleri Semineri, Meryan Otel, Antalya.

\section{Note}

Note 1. It has a great significance as 4 Grand Slam tournaments organized in season, it took a place on the organization calendar with its WTA Championships at 43 times. WTA Championships traditionally held at the end of the season was firstly launched in 1972 and since 2003 it is held by dividing into two groups that consist of the best 8 tennis player and 4 couple-teams. Turkish tennis lovers have hosted the last time in 2013 for this important organization was already hosted before in Istanbul in 2011 and 2012. The tournament will be hosted by Singapore between the years 2014 and 2018 .

\section{Copyrights}

Copyright for this article is retained by the author(s), with first publication rights granted to the journal.

This is an open-access article distributed under the terms and conditions of the Creative Commons Attribution license (http://creativecommons.org/licenses/by/3.0/). 